\title{
China, Deglobalization, and the Multinational: What Does the Next Decade Hold for Multinational Companies from the East and West?
}

\author{
Weiwen Han and James Root
}

\begin{abstract}
The Great Divergence has given way to the Great Convergence, starting with Japan's boom in the 1970s and 1980s, while soon after China's Open Door Policy became the coveted frontier of future growth. While some industries have been unable to catch the wave, industries like private equity, healthcare, consumer products and manufacturing have enjoyed success. Meanwhile, Chinese firms like Lenovo and Huawei are looking to expand globally, but have yet to see major success. While overall momentum is slowing, China will remain a key battleground for multinationals.
\end{abstract}

Keywords Great convergence - Frontier of future growth - Private equity • Healthcare $\cdot$ Consumer products $\cdot$ Manufacturing $\cdot$ China will remain a key battleground for multinationals

For centuries, Western multinationals were the apex predators of global business.

The earliest examples, the British East India Company and the Dutch East India Company, acted as quasi-governments: They controlled entire regions, issued currency, sold shares and bonds to public investors, and maintained private armies. Operating with state approval, they combined wealth creation from trade with the advancement of imperial ambition. With Japan and China largely cut off from trade under isolationist policies, European companies dominated the playing field.

These seventeenth-century pioneers and their successors rode the wave of what political scientist Samuel P. Huntington calls the "Great Divergence," a period of rapid growth in Europe that accelerated through the eighteenth century, sharply shifting the balance of global economic activity from East to West.

But more recently, the Great Divergence has given way to the Great Convergence. It started with Japan's boom in the 1970s and 1980s. Rapid domestic market growth coincided with winning innovation in industries like automotive and consumer electronics, catapulting Japanese firms to leadership beyond their home market.

W. Han $(\bowtie)$

Bain \& Company, Greater China Offices, Beijing, China

J. Root

Bain \& Company, Hongkong, China

(C) The Author(s) 2022

H. Wang and L. Miao (eds.), Transition and Opportunity, China and Globalization,

https://doi.org/10.1007/978-981-16-8603-0_13 


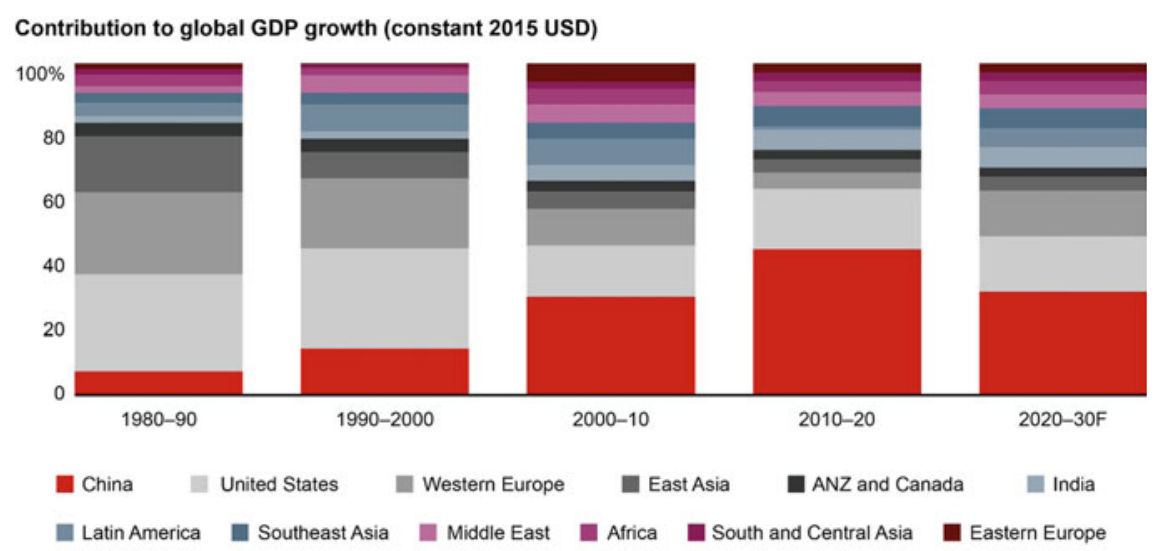

Note: ANZ is Australia and New Zealand

Source: EIU

Fig. 1 China's share of global growth could decline in the next decade

Around the same time, China's Open Door Policy allowed foreign firms to operate in the country for the first time since the mid-twentieth century. Soon enough, China had become the coveted frontier of future growth.

It's no surprise that so many multinationals have wanted to participate. Over the past decade, China accounted for nearly $45 \%$ of all growth in the world economy. But China's booming growth may be losing steam: Its share of global GDP growth could drop to about $30 \%$ over the next decade (see Fig. 1).

Simultaneously, Chinese firms have become increasingly ambitious overseas, doubling their share of all multinational sales, from $5 \%$ in 2005 to $10 \%$ in 2018 . Firms such as Lenovo, Haier, WH Group, and China State Construction have become major international competitors.

We're now moving into another phase in the evolution of global trade. Geopolitical tensions are escalating. Some companies are reshoring production in the wake of COVID-19 supply chain disruption. Regional champions from emerging markets are gaining momentum. Non-Chinese multinationals may find that China does not hold the promise it once did, and Chinese multinationals may rediscover what they already knew: Their greatest growth opportunities lie right in front of them.

\section{Can Multinationals Still Win in China?}

China's breathtaking scale and sustained 40-year expansion helped multinational firms across industries grow their businesses, learn new skills, and create new partnerships. 
But the China hypergrowth years are now well behind these firms. The market share of multinationals in China has started to reverse its long upward trajectory, falling from an aggregate $16 \%$ of the Chinese economy in 2005 to $10 \%$ in 2018.

Many leading multinationals have had limited to no opportunity to catch the China wave-at least not yet. Cutting their losses, some marquee companies such as Auchan, Amazon, and Uber have withdrawn or scaled back. In several industries, almost no multinationals have attractive businesses in China:

- Tech. The partial list of companies struggling to compete in China includes Facebook, Google, Twitter, and Snapchat. Even those hardware companies that have fared far better-Qualcomm, for example_-will soon face an uphill battle. With the US and Chinese economies and technology ecosystems likely to be moving toward a decoupling, sustaining profitable growth in China will be even more challenging.

- Retail. China has been a graveyard for the ambitions of many international retailers. They have often been unable to keep up with local rivals, failing to match their cost position or meet their speed of decision-making on assortment, pricing, and other aspects of category management. Most critically, they have often struggled to replicate local firms' swift pivot to digital and online-to-offline commerce over the last 5-10 years.

- Media. The top 10 media companies in China are all local. Because of restrictions on foreign companies, most of the world's largest media companies have no presence in the country.

- Telecommunications. China's telecom industry also remains almost entirely protected from foreign competition.

However, there are also some sectors where multinationals enjoy great success:

- Private equity (PE). Despite tough competition from local funds for LPs, deals, and talent, a number of international PE firms have built superb businesses in China. These winners have benefited from their global networks for deal flow, as well as decades of experience in due diligence, value-creation planning, and post-acquisition operational improvement.

- Healthcare. Multinationals have seized opportunities across primary care, elder care, healthcare professional training, oncology, fertility, orthopedics, dental treatment, ophthalmology, and diagnostic imaging. Although private local providers have emerged in these areas, there is plenty of room for foreign players with expertise and new technologies.

- Consumer products. For several decades, China has been a primary growth market for consumer goods. While Chinese brands have gained share across food and beverage, home care, and personal care categories over the last five years, multinational brands remain formidable competitors.

- Manufacturing. In low value-added manufacturing, multinationals have historically found it difficult to compete with lower-cost Chinese producers. However, 
as value-add increases-for example, in automotive, elevator systems, chemicals, or aerospace-multinationals enjoy more success. In fact, China is their key battleground.

There's also the shifting landscape of financial services. The regulatory exclusions on foreign participants are starting to ease across sectors. While Chinese firms still dominate in banking and insurance, increasingly, multinationals such as PayPal, BlackRock, and Allianz are able to revisit their China strategies with greater ambition.

Although results vary by industry, one conclusion is clear: It is possible to thrive as a multinational without a big business in China, or even any business there at all. Lack of a strong China business may be a source of regret-and certainly, a reason to stay alert to change-but it is not an existential threat.

While China will remain uniquely influential in the coming years, growth markets will diversify. Other countries will take a greater share of the growth pool in aggregate. At the same time, as we move into a multipolar world order, geopolitics will increasingly inhibit non-Chinese multinationals' strategies in two ways.

First, geopolitical tensions between the US and China are mounting, as evidenced by tariffs from the Trump administration, bans on Chinese network equipment, foreign ownership constraints, and more. The fallout is reversing years of open, global trade. Technology companies are already feeling the impact acutely, as both nations race for leadership in new digital technologies.

Second, multinationals dependent on both China and their domestic markets will find the balancing act increasingly difficult. Governments have their proprietary agenda - in data privacy, environmental responsibility, labor rights, accounting standards, and more - often creating conflicting demands.

Navigating the geopolitical conflicts may overwhelm some firms, causing them to fold their hand or dial back in China. For others, new governance models or capital structures for their China business will help to manage the tensions.

\section{Can Chinese Multinationals Gain Ground?}

At first glance, the numbers suggest a gathering crowd of Chinese firms eyeing international expansion. Since 2005, the foreign sales of Chinese multinationals have grown at a compound annual rate of $10 \%$, more than double the rate of US, Japanese, and European firms. There are now 3,400 Chinese multinationals, almost as many as those from the US and Western Europe combined.

Just as the Industrial Revolution triggered Europe's booming growth during the Great Divergence, the digital revolution accelerated China's reemergence as an economic powerhouse. Chinese firms are now among the global pacesetters in areas of digital innovation, from e-commerce, to gaming, to payments, to artificial intelligence. 
Early pioneers like Lenovo, Haier, and Huawei paved the first paths of global growth. Their efforts were bolstered by China's admission to the World Trade Organization in 2001, and, often, by skillful acquisitions of Western brands.

The scale infrastructure projects, mostly in emerging markets, that came with the launch of the Belt and Road Initiative in 2013 enabled rapid overseas growth for firms involved, including China State Construction and COSCO Shipping. These projects also helped to pry open market access for Chinese firms in other sectors.

Over the past decade, the group of firms sustaining the international growth momentum has expanded: Think of Vivo in smartphones, Tencent in gaming and messaging, Geely in automotive, Wanhua in chemicals, and LONGi Green Energy in solar wafers. More recently, a new wave of mold-breaking firms in sectors such as payments, healthcare, and delivery have made it clear that international growth is a high priority - just consider Mindray or SF Holdings.

It's no wonder that the list of Chinese multinationals appears to be growing. But in reality, the early leaders are starting to look more like a group of exceptional pioneers than an advance guard blazing a trail for the rest. The ranks of scale global Chinese multinationals are, in some ways, surprisingly thin. While a sector-by-sector view reveals many Chinese firms that value international growth, these firms differ from other multinationals.

For one, foreign sales are a much smaller portion of their business (see Fig. 2). They also remain primarily focused on smaller and emerging markets over the larger profit pools of Western Europe and North America. In addition, these firms keep the majority of their manufacturing in China, rather than end markets.

What's more, three challenges will check the future international growth of Chinese multinationals.

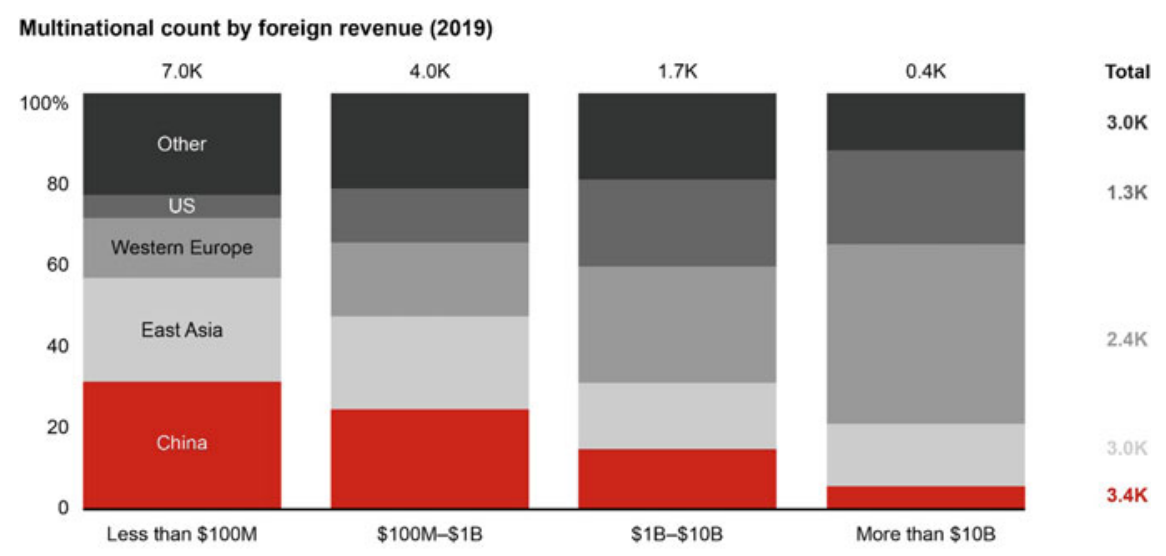

Notes: Listed companies only: multinational defined as a firm with sales from foreign operations; China includes Hong Kong Sources: Refinitiviv, Bain analysis

Fig. 2 While China leads in multinational firms, most of them have only a small presence abroad 
First, there are once again geopolitical tensions at play. Consider how the USA placed Huawei and ZTE on the Entity List, or how the Trump administration pressured TikTok to become part of a US-based company. If relations between China and the West continue to deteriorate, restrictions on Chinese firms may extend beyond sensitive technology. While Chinese multinationals may continue to find access to emerging economies from Belt and Road programs, they are likely to face increased resistance in their Western expansion efforts. Despite slower growth, Western markets still make up more than half of the global economy.

Second, Chinese brands have struggled to resonate with foreign consumers. Of Forbes' list of the 100 most valuable global brands, just one is Chinese. Western brands possess cultural soft power, while Japanese and Korean firms have patiently built exemplary brands over the last 50 years.

Nothing is stopping Chinese firms from replicating their success, but it hasn't happened yet. So far, Chinese brands have primarily won in their domestic markets. Yet their innovation investments and R\&D focus in the last decade have paid dividends - it is now a soft-minded anachronism to dismiss Chinese firms as mere copiers and fast followers.

Finally, firms in China are facing a shift in policy environment. Over the past decade, their margins have deteriorated in the face of weakening global demand and increased competition from alternative manufacturing locations. The aggregate return on capital for listed Chinese firms has dropped well below their cost of capital (see Fig. 3). To fund continued expansion amid falling profitability, Chinese firms have relied increasingly on debt-an approach that threatens the sustainability of their growth trajectory.

The government is now applying pressure to rein back leverage-fueled international growth. Announcing a "dual circulation" economic strategy, it plans to

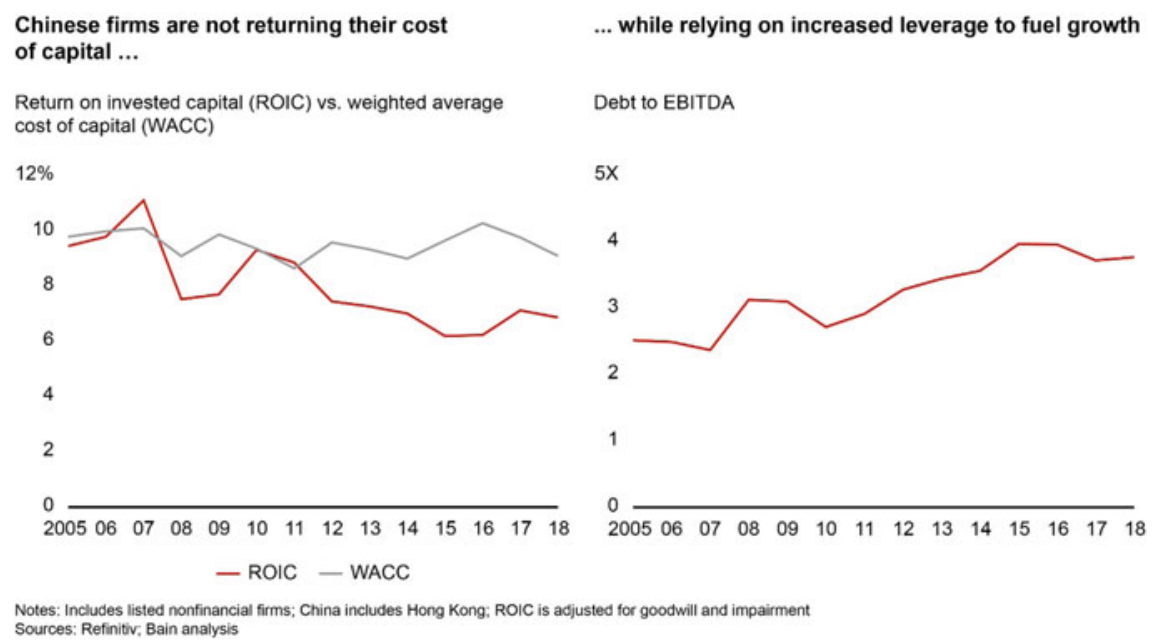

Fig. 3 Chinese firms are increasingly relying on debt to fuel growth amid falling profitability 
increase dependence on "internal circulation," or domestic production, distribution, and consumption, rather than looking overseas.

The recent successes of firms like Wanhua, Mindray, Tencent, and Vivo are impressive. But overall, we should not expect a widespread push toward international growth at scale from Chinese multinationals in the next decade.

Globalization, primarily bolstered by multinationals, has been one of the tailwinds propelling a golden age of corporate profitability over the last 40 years. The current geopolitical state is certainly reducing the speed of that tailwind and maybe even pushing it into reverse.

Notwithstanding, China will continue to be an attractive growth market-especially if yours is a Chinese or localized firm.

Acknowledgements The authors would like to acknowledge the contributions of Andrew Schwedel, and Kevin Chang, Partners of Bain \& Company, Thomas Devlin, the practice senior manager for Bain Futures.
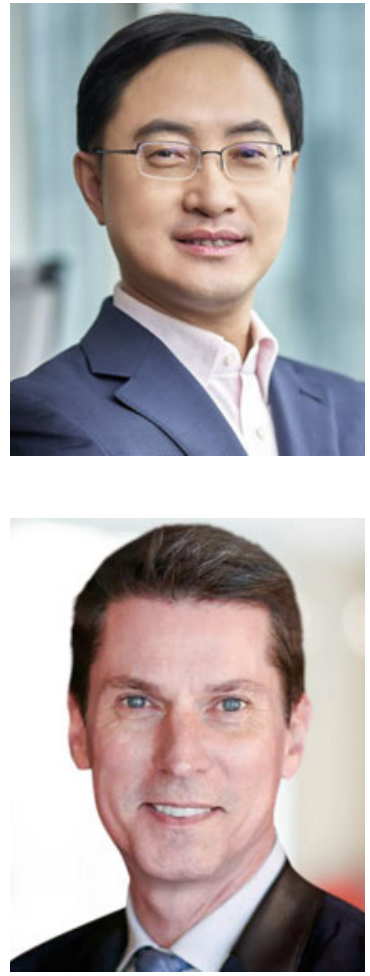

Weiwen Han is the managing partner of Bain \& Company's Greater China offices and a member of the firm's Board of Directors. He is a leader in the firm's Private Equity practice and a senior member of the Digital, Consumer Products, and Retail practices, as well as an expert engaged with Bain's Founder's Mentality 100 program. Weiwen has more than 25 years of management consulting experience. He has helped many large-sized Chinese companies to develop strategies, improve their performance, and upgrade their management capabilities. Weiwen earned an MBA from the University of Chicago Graduate School of Business. He also received a Bachelor of Science degree from Fudan University.

James Root is a senior partner in Bain \& Company's Consumer Products and Organization practices, based in Hong Kong. He is the chairman of Bain Futures, a proprietary global think tank, which tackles the client implications of coming trends. With more than 30 years of experience across Europe, North America, and Asia-Pacific, James focuses on corporate transformations involving strategy, cost management, operational improvement, and organizational effectiveness. He has been published extensively on branding, international expansion, growth strategy, and the Firm of the Future across the business press. James holds an MBA from London Business School and a BA from the University of Cambridge. 
Open Access This chapter is licensed under the terms of the Creative Commons AttributionNonCommercial-NoDerivatives 4.0 International License (http://creativecommons.org/licenses/bync-nd/4.0/), which permits any noncommercial use, sharing, distribution and reproduction in any medium or format, as long as you give appropriate credit to the original author(s) and the source, provide a link to the Creative Commons license and indicate if you modified the licensed material. You do not have permission under this license to share adapted material derived from this chapter or parts of it.

The images or other third party material in this chapter are included in the chapter's Creative Commons license, unless indicated otherwise in a credit line to the material. If material is not included in the chapter's Creative Commons license and your intended use is not permitted by statutory regulation or exceeds the permitted use, you will need to obtain permission directly from the copyright holder.

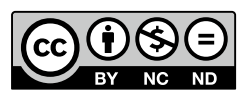

